\title{
MINUTES OF PROCEEDINGS
}

\section{ELECTIONS}

The Council at their meeting on 15 July, 1958, in accordance with By-law 14, declared that the following had been elected as Associate Members.

Brest, Stanley Herman, B.Sc. (Cape Kerr, Geoffrey Brian, Grad.I.C.E. Town), Grad.I.C.E.

BURNSIDE, William SPIERS, Grad.I.C.E.

FITzMaurice, JoHN ROBert, S.M. (Harvard), B.E. (New Zealand), Grad.I.C.E. Frewin, Thomas Frederick, Grad.I.C.E. Hobbs, John Michael Somerset, Grad. I.C.E.

JoNES, RoBin Bethune, B.E. (Tasmania), Grad.I.C.E.
MCKenzie, Hugh Borland, Grad.I.C.E.

O'Donovan, Carroll Joseph, B.E. (New Zealand).

SAmuel, Peter, B.Sc. (Eng.) (London), Grad.I.C.E.

Smtth, Frederick Roland, B.E. (New Zealand).

\section{DEATHS}

It is with deep regret that intimation of the death of the following has been received.

\section{Members}

AleXander Colin Anderson, O.B.E. (E. 1909, T. 1920).

Bernard Gerard Carroll (E. 1938, T. 1957).

HeNRy John Green, O.B.E., M.C. (E. 1934).

JoHn Francis Sherwood TyLeR (E. 1914).

\section{Associate Members}

Allan Waddell (E. 1911).

WILliam LaW WaTSON, C.B.E. (E. 1911).

\section{OBITUARY}

FREDERICK ALFRED GREAVES, B.Sc.(Eng.), M.I.C.E., who was born on 11 October, 1894, died on 21 March, 1958.

Educated at West Ham Municipal Secondary School and West Ham Technical College, he obtained his degree at London University in 1914. He began his professional career as Assistant Engineer on the Tilbury Main Docks Extension. From 1916 to 1919, while serving in the Royal Engineers, he was granted a commission. After military service he was Assistant Engineer to J. Walston Twinberrow, the Consulting Engineer on the layout and design of a shipbuilding yard for Ghent, Belgium. In 1921 he joined the staff of Messrs Rendel, Palmer \& Tritton, Consulting Engineers, and worked on the design of the extension to Lonsdale Dock, Workington, and the reconstruction of the dock walls for Ridham Dock. For the latter work he became Resident Engineer in 1923.

In 1925 he undertook, as Assistant Engineer, the design of various works for the construction of the Takoradi Harbour, Gold Coast. Later, he supervised the machinery subcontracts for the Tilbury New Entrance Lock and Dry Dock, and also for the West India Dock Entrance. In 1929 he was appointed Assistant 
Engineer on the design of, and in 1932, Senior Assistant Engineer on the construction of, Haifa Harbour and its equipment; in 1933 he became Chief Assistant Engineer. In 1939, at the head office of Messrs Rendel, Palmer \& Tritton, he was Engineer in Charge of the preparation of the contract and designs for the Riverside Quay, Tyne Improvement Commission, and the design and construction schemes of Mashur Oil Port Development in the Persian Gulf. During the 1939-45 war he carried out a variety of work for War Department Storage Depots.

He was made a partner in the firm of Messrs Rendel, Palmer \& Tritton in 1946, and retired from active work in November, 1957.

Elected an Associate Member in 1923, he was transferred to the class of Members in 1941.

Lieutenant-Colonel MERVYN JOSEPH PIUS O'GORMAN, C.B., D.Sc., M.I.C.E., M.I.Mech.E., M.I.E.E., who was born on 19 December, 1871, died at his home in Chelsea on 16 March, 1958.

He was educated at Downside, and at University College, Dublin, where he took degrees in Classics and Science. He studied electrical engineering at the City and Guilds Institute for two years, and began his career with Fowler Waring Cables Co. Later he became Manager of Cie Générale des Cables Electriques in Paris, and then was appointed Consultant Engineer to Glover and Co. (Cables). Previous to 1909, when he became Superintendent of H.M. Royal Aircraft Factory at Farnborough, he was in partnership with Cozens-Hardy, and then with Swinburne and Baillie.

During his service as Superintendent he reported on European Aeronautics with Admiral Sir M. Sucter in 1912. In 1917 he was sent to report on the Italian Front with Air Commodore Babington. From 1916-1919 he was Consulting Engineer to the Director-General of Military Aeronautics; 1919-1929 he was President of the Technical Commission of the Fédération Aéronautique Internationale, Chairman of the Accident Investigation and Civil Air Transport Committees of the Air Ministry, Chairman of the Adhesives Committee of the Department of Scientific and Industrial Research; 1923-1931, Vice-Chairman of the Royal Automobile Club, and in 1952 he became Vice-President; 1931, Chairman of the League of Nations Sub-Committee on Rating Aeronautical Engines; 1910-1937, Vice-President of the Association Internationale des Automobiles Club Reconnus, and also of the Fédération Internationale Aeronautique, Paris; 1928, Vice-Chairman Royal Aero Club, and in 1934, Vice-President.

A founder member of the Royal Flying Corps he was a pioneer of aeronautical engineering and published several articles on the subject. He also published O'Gorman's Motor Pocket Book in 1908.

He was elected Member in 1917.

ADRIAN BENSON PORTER, M.I.C.E., M.I.Mech.E., who was born on 19 April, 1899, died on 18 April, 1958.

He was educated at Liverpool Collegiate School, and served his engineering apprenticeship (1915-1920) with the late Thomas M. Newell, M.I.C.E., Engineerin-Chief, Mersey Docks and Harbour Board. He continued his engineering career in the same office from 1920-28 under Mr Newell, and then from 1928 under Mr T. L. Norfolk, who in that year succeeded Mr Newell as Engineer-inChief. 